\title{
POLITICS OF NGOS IN POLITICAL CRIMES
}

\author{
Ali Asghar Ranjbar ${ }^{1}$ \\ Mohammad Hassan Hassani ${ }^{2}$ \\ Rohodin kord alivandi ${ }^{3}$
}

\begin{abstract}
Non-governmental
the Samans can act in their other role as organizations, which today are seen as a manifestation of participatory criminal policy, play an important role in the realization of victims' rights in most crimes, which is known as the policy of the Samans; But the question is, can this the declarants of a political crime, which the legislature also mentioned in Article 66 of the Criminal Procedure Code adopted in 1392. And although the obvious feature of the Samans is their non-profit and non-political nature.
\end{abstract} also play a role in political crime? Political crimes, which have been widely defined, can have broad meanings, and political crimes in the present article refer to crimes that are in conflict with the basis of the revolution. And as a crime under specific and general laws provided by law; therefore, in this type of crime, which is also a specific crime and is often unforgivable, and until they have a private aspect, the Samans must examine how the Samans can intervene. However, in addition to the supportive aspect of the Samans, it can be stated that

Keywords: NGO, politics, political crime, government, criminal proceedings.

\section{INTRODUCTION}

Politicians, legislators, statesmen, criminologists, and jurists directly recognize the victim and his or her dependents who have experienced his or her crime for any reason as deserving of the material, spiritual, and psychological guidance and assistance of the government and civil society. And

\footnotetext{
${ }^{1} \mathrm{PhD}$ student in Criminal Law and Criminology, Islamic Azad University, Damghan Branch (Corresponding Author) ali.ranjbar.31@gmail.com, https://orcid.org/0000-0002-0990-1644

2 Assistant Professor and Faculty Member of Islamic Azad University, Damghan Branch m_hasani@du.ac.ir, https://orcid.org/0000-0002-1499-1760

3 Member of Islamic Azad University, Damghan Branch r_alvandii@gmail.com, https://orcid.org/0000-0002-6745-5750
} 
they believe that on the one hand, in the process of criminal proceedings and judicial orientations at the time of the initiation of criminal prosecution, trial and sentencing, more attention should be paid to his views and demands. On the other hand, like the offender, he should be included in the treatmentrehabilitation and social reconstruction programs, because he has suffered material and spiritual, especially psychological, especially in violent crimes, and has suffered many losses and disorders. That's why they need help and help, and finally repair. Accordingly, it is also the ideological-supportive approach that the criminal legislature pays more and more attention to the demands and destiny of the victim in the criminal process from the moment of prosecution to the manner of execution of the sentence. In this way, the element of crime promises an orbital vision in substantive criminal law. One way to protect the rights of victims is to use the potential of society and informal institutions to strengthen this supportive approach; but the important question can be asked whether a supportive approach can be taken in political crimes as well, and whether the structure of the Samans, which is non-political, can be studied at the same time. We will examine all the non-political features and how the Samans can intervene in political crimes in the present article.

\section{CONCEPTOLOGY}

The concept of nongovernmental organizations

The definition and concept here refers to the clear and distinct expression of the concept of non-governmental organization, so that based on this definition, firstly, the ambiguities resulting from the misuse of this term can be removed and secondly, its identity can be distinguished from other recognition matters. In the third step, comprehensively stated the criteria and norms related to it. We adjust our activities according to our perception of things. Our perception of anything plays an important role in our relationship with it. We deal with it according to the definition we have of the nongovernmental organization. For this reason, before any discussion, we must critique our perception of what a nongovernmental organization is (Faramarz Gharamaleki, 2006: 31).

The most important factor for NGOs is their social identity. Such organizations necessarily have the 
structure of a social group. Although in the beginning Saman may be invented by one person, even its establishment is collective in nature. The fact that nongovernmental organizations are an important part of civil society is due to their collective identity. Since paying attention to this role plays an essential role in understanding moral responsibilities and moral values and criteria, and the moral orientation and performance of the social group is much more complex than the moral performance of the individual to explain and explain more and more the concept of social group and We are dealing with civil society (Niebur, 1932: 124) Social group refers to groups of people who interact with each other on a regular basis. Groups may range from very small institutions to large organizations or communities. Regardless of the size of the group, one of its defining characteristics is the awareness of the group members of the common identity. Most of our lives are spent in group relationships, so that in today's society most people belong to different types of groups (Giddens, 2004: 790). Because having relationships and interactions and influences and awareness of a collective identity is one of the main components of social groups. Therefore, these groups are beyond, better and more important than any common social and collective gatherings or groupings, including statistical groupings (Scott, Gordon, 2005: 257). But civil society is one of the concepts that has been much discussed recently, and there are many disagreements about it, but all of these views occur. This part of society belongs to the realm of public activity, not private or personal, and operates within the framework of existing laws. It mostly involves voluntary participation in public affairs, including mass communication, trade unions, and unions. Civil society is the middle part of society and the liaison between the private sector and the state, and the way it is understood and interpreted and familiar with its positive and negative capacities has a great impact on voluntary collective actions such as semen (Faramarz Gharamaleki, 2009: 15). However, unlike governments, Saman is not subject to international law, with the exception of the Red Cross, which is subject to the Geneva Convention. The Council of Europe in Strasbourg drafted the European Convention on the Recognition of the Legal Character of the International 
Non-Governmental Organization in 1986, which was the legal basis for the presence and activity of the Samans in Europe. Article 11 of the European Convention on Human Rights, which guarantees the right to freedom of association and association, is also a fundamental principle for Samans. In each organization, two analyzes must be considered: the analysis of the organization's pillars and its environmental analysis; Saman's moralization cannot be realized without these two analyzes. Every organization has pillars, including human resources, job description, technology and organizational structure, which play an essential role in achieving the goals of non-governmental organizations (Faramarz Gharamaleki, 2009: 16-15).

\subsection{The concept of political crime}

Political crime in Iranian law has not been studied in a narrow, comprehensive and complete manner, but in the Law on Political Crime approved in 2016, the legislature has defined political crime; Article 1 of the said law states: "If any of the crimes permitted in Article (2) of this law are committed with the motive of reforming the affairs of the country against the management and political institutions or domestic or foreign policies of the country, It is a political crime without the perpetrator intending to harm the principle of the system."

Article 2 also states: "The following offenses shall be considered a political crime if they comply with the conditions set forth in Article (1) of this Law.

A: Insult or defamation of the heads of the three branches, the chairman of the Expediency Discernment Council, the deputies of the President, ministers, members of the Islamic Consultative Assembly, members of the Assembly of Experts and members of the Guardian Council due to their responsibilities.

B: Insulting the head or political representative of a foreign country who has entered the territory of the Islamic Republic of Iran in accordance with the provisions of Article (517) of the Islamic Penal Code of the Penitentiary Department

$\mathrm{C}$ : Crimes mentioned in paragraphs (d) and (e) of Article (16) of the Law on the Activities of Parties, Populations, Political and Trade Unions and Islamic Associations or Religious Minorities, approved on 06/07/1360 
D: Crimes stipulated in the election laws of the experts of the leadership, the presidency, the Islamic Consultative Assembly and the Islamic councils of the city and the village, with the exception of the executors and observers of the elections.

\section{E: Publishing lies.”}

However, it can be stated that the framework of the definition and nature of political crime has been studied in the articles one and two of the political crime law. However, in previous legal periods, the legislature did not provide a precise concept, and jurists did not provide complete and comprehensive definitions.

Legislative policy governing the Samans in line with political crimes

\section{CONSTITUTION}

Given the capacity of the constitution, it is essential that government agencies in the field of legislation and implementation, with normal legislation and the issuance of the necessary instructions, provide favorable conditions for the activity and strengthening of non-governmental organizations. To make it more possible for the political system to develop and increase its capabilities; Unfortunately, in the constitution, in that true sense, the issue of the involvement of the Samans in the declaration of crime, as well as political crimes, has not been studied.

However, the question is whether the establishment of a new body called the Dispute Resolution Council, along with the official courts of justice, is in accordance with the principles of the Constitution in order to be considered a safe haven. And can this institution act in order to declare a crime in political crimes? According to Article 159, it is the source of the grievances and complaints of the judiciary. The jurisdiction of the judiciary in dealing with grievances and complaints is inherent, so the creation of jurisdiction to deal with grievances for an authority other than the judiciary and the disqualification of the judiciary under ordinary law is clearly contrary to this principle (Rahgosha, 2004: 58).

Especially since these councils are not considered courts at all, and thus the people are deprived of the right to sue in the courts of justice. Article 36 of the Constitution also stipulates: "The sentence of punishment and its execution must be carried out only through a competent court and in accordance with the law." Therefore, considering that in 
some cases, these councils are also authorized to issue fines, in this case, it is also in conflict with the constitution. Article 61 of the Constitution stipulates that "the actions of the judiciary shall be governed by the courts of justice, which shall be established in accordance with Islamic law and shall settle disputes and protect public rights and the administration of justice and the observance of divine limits."

Therefore, the constitution stipulates the application of the judiciary by the courts of justice, and these councils are not considered courts. Therefore, the constitution contradicts this principle. In practice, the Dispute Resolution Councils may reduce the heavy burden of cases in the judiciary and have other benefits, but this practice and the preference of benevolent intentions and goals over the constitution is itself a source of tyranny and lawlessness (Amini, 2014: 168-167). Like the laws before the revolution, in the laws and regulations after the revolution, the participatory criminal policy approach in the form of various legal facilities and in the form of concepts of the family of restorative justice Such as compromise, compromise, reform of the essence of vision, judgment and judgment can be seen in scattered cases. Article 156 of the Constitution of the Islamic Republic of Iran considers one of the duties of the judiciary in paragraph 1 of this principle after the duty to issue judgments on violations and complaints, settlement of lawsuits and "elimination of hostilities"; Elimination of hostility, resorting to peaceful measures such as mediation and compromise, compromise and reform of the essence of the vision reminds the parties of hostility (Amini, 2014: 150). However, it can be argued that nongovernmental organizations are not provided for in the true sense of the word in the constitution, therefore, dispute resolution councils cannot be accepted as Saman. Thus, the Samans have not been enshrined in the constitution until the scope of their involvement in political crimes is examined.

Islamic Penal Code adopted in 1392

\section{Non-governmental}

organizations have a very important role in the fall of the penalties provided for in the law, such as obtaining a pardon, which is of great importance in mitigating the punishment or parole, and so on. This is less the case with political crimes of a public nature. One of the 
political crimes mentioned in the law on political crime is insulting the president or political representative of a foreign country that has entered the territory of the Islamic Republic of Iran in accordance with the provisions of Article 517 of the Islamic Penal Code (Penitentiary Department approved in 1996). This is an unforgivable crime.

In the Islamic penal system, the tendency to reduce the role of the professional judge and try to find informal solutions, such as nongovernmental organizations in resolving disputes, has a special place. This, which creates the grounds for people's participation and popularization in resolving disputes, plays a significant role in resolving disputes and preventing resentment and increasing social solidarity by encouraging newcomers to reach agreement and compromise and promoting the spirit of benevolence and religious brotherhood. In this system, the exclusive competence of official judges in resolving disputes is eliminated, so anticipating measures that, in addition to reducing the burden on the judiciary, will save the defendants from lengthy formalities and waste of time and money, is one of the goals of this system. "Mediation between the parties to the dispute is one of the valuable measures that will ultimately lead to peace and reconciliation. In Islamic culture and law, the word "mediation" is used in two senses: one to mediate between two hostile parties, in order to pardon the aggressor by the victim, in order to resolve differences and create peace and reconciliation between the two, the other, mediation. And intercession with the ruler (judge) for the benefit of the offender in order to pardon and forgive him or to reduce his punishment" (Hosseini, 1999: 6). Therefore, the Islamic Penal Code adopted on 1/2/1392 has high capabilities and capacities in order to achieve the goals. Therefore, it can be stated that the Samans have a very important role in the implementation of the policies in the Islamic Penal Code adopted in 1392 as a policy of decriminalization and decriminalization, which is more limited in terms of political crimes.

\section{Criminal Procedure Code approved in} 1392

Another important law that refers to the role of the Samans is the Code of Criminal Procedure adopted in 2013; Article 66 of the law establishes the position of the Samans and declares 
the activities of the Samans to be nonpolitical, and the Samans can declare any crime, whether political or non-political. With the amendments made in 1352 to the provisions of the Code of Criminal Procedure, by adding Note 2 to Article 8 of the Code of Criminal Procedure, the number of forgivable offenses increased and the legislature expelled 210 articles or applied publicly contrary to public decency and 213. The General Penal Code enacted a number of forgivable offenses (Note 3 to Article 8) to adopt a more realistic criminal policy on forgivable offenses, but has remained silent on political offenses. Thus, it can be said that before the Islamic Revolution, although the principle of non-forgivable crimes had been considered by the legislature, the

\footnotetext{
${ }^{4}$ To learn more about the crimes that can be committed before the Islamic Revolution, the most important things that the plaintiff's complaint was necessary to file a complaint are:

- Crimes against chastity and public morality and family duties: In this regard, sodomy crimes, insulting honor, act contrary to chastity other than insulting honor, illegitimate relationship, remission of virginity, cheating one's partner in marriage, marriage Again, without obtaining permission from the court, leaving the charity, etc., can be considered a forgivable crime, and the plaintiff could have played a serious role in prosecuting or canceling it.

- Crimes against property and possessions: in the crime of unchecked checks, destruction of private property, entry into property other than violence and domination, deceiving the customer in terms of quantity with the quality of sale, registration of other property, preparation of works in other lands and properties, entry into Violence against another property by staying in it with violence and domination and aggressive possession, etc., the plaintiff's
}

legislature counted the cases of forgivable crimes, which amounted to more than 30 cases, in the law itself and on participation and role. The victim insisted on prosecuting or withdrawing from the crime and clarified the task of the suspects and judges (including the prosecutor's office and the courts) in advance, and even in Article 66 of the Code of Criminal Procedure. Repealed on $11 / 2 / 1352$, he had obliged the plaintiff to summon the litigants and assign them to compromise in forgivable crimes. Also, Article 68 of the General Penal Code (Amended on 3/7/1352) in crimes that were subject to the complaint of a private plaintiff, had considered a 9month lapse of time to announce the complaint (Ashoori, 2012: 1/141). ${ }^{4}$ The Code of Criminal Procedure, passed on

complaint was a condition for the prosecution to be prosecuted. Conversely, crimes of theft, betrayal of trust and fraud, except in cases where the perpetrator has committed adultery or causal or relative closeness so that there are certain degrees between them, and some other crimes against property, are unforgivable crimes, which the prosecutor's office is obliged to The pursuit of them was considered.

- Crimes against the physical and mental integrity of persons: The legislature inflicts intentional bodily harm (even with the deprivation of the right to work for more than 20 days), unintentional bodily injury resulting from traffic accidents, intentional breaking of an organ and even disability in crimes resulting from traffic accidents. Without leading to a complete defect of the member - provided that the perpetrator of the spouse or from a relative to the third degree or causal to the second degree is a private plaintiff. It was forgivable. Conversely, a stab wound, amputation or disability, or complete disability of an insane member as well as a permanent illness, lack of one of the senses and dementia, and in the first way murder, both 
$12 / 4 / 2013$, has raised issues in various articles and has provided facilities that reduce the burden of justice and avoid the disadvantages of the official criminal justice system. That in itself is a step in the direction of "judicial justice" policy. Therefore, the various articles of this law, which have been developed in line with the judiciary, are briefly examined:

1. Article 1 of this law, which defines the Code of Criminal Procedure, describes it in such a way that it includes mediation, peace and reconciliation between the parties to the criminal case. Given that in accordance with the classical criminal justice system, the penal system is basically seeking to punish the perpetrators, therefore, the laws of criminal form should be regulated in such a way as to achieve this goal, but the law is in line with new approaches. Restorative justice and criminology of social reaction have a special place for mediation, peace, reconciliation and reform of the essence of vision, which is quite clear from the

intentional and unintentional, were unforgivable, and the court could cite Article 192 of the General Penal Code, if the plaintiff or private plaintiff is pardoned, shall sentence the perpetrator to a minimum sentence or reduce the sentence by one degree and, in the case of execution, by two degrees. definition of criminal procedure. "The Code of Criminal Procedure is a set of rules and regulations established for the detection of a crime, prosecution of a defendant, preliminary investigation, mediation, peace between the parties, etc." For this reason, this law has taken a step towards justice by predicting mediation and peace and reconciliation (Amini, 2014: 154-153).

2. Article 12 of the Code of Criminal Procedure, adopted in 1392, stipulates: "The prosecution of a defendant in forgivable crimes shall begin only with the complaint of the plaintiff and shall be terminated upon his pardon. Thus, the plaintiff's pardon, which is usually obtained through a special process through the mediation and mediation of individuals, prevents the continuation of the criminal process, which is itself a kind of participatory criminal policy.

3. Article 13 of the said law provides for cases such as amnesty, inclusion of time, plaintiff's pardon and repentance of the accused, which leads to

In addition, in the case of crimes against the spiritual integrity of individuals, insult, defamation, public insult to the President of a foreign country with its political representative in Iran, insult and defamation to the Minister or Member of Parliament or Judge through the press, etc. Crimes were considered forgivable. See also: (Ashoori, 1997: 195) 
the endowment of prosecution, and each of the above cases removes the case from the trial process, which according to Explaining the above-mentioned issues in previous discussions in order to avoid prolonging the speech, it is refused to explain them (Amini, 2014: 154).

4. One of the final appointments that was foreseen in the Code of Criminal Procedure of the General and Revolutionary Courts approved in 1378 and is also stipulated in the Code of Criminal Procedure of 1392 is the appointment of "leaving the prosecution". Article 79 of the latter law refers to this appointment. The order was passed on the offenses and will be issued by the prosecutor at the request of the plaintiff before the indictment is issued. The issuance of this order has no effect on the validity of the closing order, so the plaintiff can request the prosecution of the accused devotee only once for one to one year from the date of issuance of the dismissal order. ${ }^{5}$

5. The "case file" agreement is also one of the agreements stipulated in Article 80 of the Criminal Procedure Code approved in 2013. This order can

\footnotetext{
${ }^{5}$ In this regard, the manifestations of participatory criminal policy in the present dissertation are mentioned.
}

be issued by the judicial authority under certain conditions. If the plaintiff has not been convicted or pardoned, if there is no record of the history of effective criminal convicts, after being informed of the charges, considering the social status and records of the accused and the circumstances that led to the crime. If necessary, by obtaining a written commitment from the accused to comply with the legal regulations, it can be issued only once (Amini, 2014: 155).

6. In order to fulfill the principle of suitability or suitability of prosecution, as well as to prevent the labeling of individuals and reduce the criminal population, the prosecutor has been granted a transaction charge; In other words, according to the law, the prosecutor is allowed to suspend the prosecution of the accused for a certain period of time by issuing a "suspension order" if there are special circumstances. This appointment is provided for in Article 80 of the Code of Criminal Procedure of 1392, and special conditions are provided for its issuance. Including the fact that this order can only be issued in sixth, seventh and eighth 
degree criminal offenses. Also, in order to issue it, there should be no plaintiff or pardon or compensation for damages, or with the consent of the victim, the payment order should be given within a certain period of time and the defendant should not have an effective criminal record. Suspend six months to two years. Of course, the prosecutor may, as the case may be, order the execution of certain orders, such as quitting addiction by visiting a doctor, clinic or hospital, or any other means, within six months, refusing to work or a certain profession for a maximum of one year, and so on. (Amini, 1393: 155).

7. One of the most important aspects of participatory criminal policy, as provided for in the new law, is the referral to "mediation." This is stated in Articles 82 and 83 of the new Code of Criminal Procedure. In the sixth, seventh and eighth degree criminal offenses, the judicial authority can, at the request of the accused and with the consent of the victim or private plaintiff, provide the defendant with a maximum of two months to obtain appropriate compensation to study the plaintiff's pardon or compensation for the crime. The judiciary has also been allowed to refer the matter to the Dispute Resolution
Council or to a person or institution for mediation with the consent of the parties to reach a compromise between the parties, which is not more than three months. This deadline can be extended only once if necessary. If the plaintiff is acquitted, the prosecution will be suspended. If the judicial authority accepts the defendant's request and the victim's consent is granted, it will give the defendant at least two months to apply for the acquittal of the plaintiff or compensation for the damage caused by the crime. If the judicial authority agrees to the request to refer the matter to mediation, the mediation period is 3 months. Of course, these periods can be extended only once if necessary. That is, the maximum deadline for the defendant's request is 4 months and the maximum referral to mediation is 6 months, and this period can no longer be extended!! Of course, the reason for the legislator's disagreement with the extension of the mentioned deadlines is not very clear, but it seems that the legislator's goal is to prevent the delay of the trial (Goldost Joybari, 2014: 104103).

8. Today, due to the requirements of human rights and the protection of the rights of the accused and considering the 
principle of equality of arms, on the one hand, the powers of the prosecutor have decreased, but on the other hand, according to other interests, including policies to reduce the criminal population. Prosecutors and prosecutors have increased the prosecutor's powers. The institution of "deviation from the indictment" is one of the mechanisms that have been created in line with this goal. Such an institution has never had a precedent in the laws and regulations of Iran, either before or after the revolution, and is envisaged for the first time in the new law. According to Article 283 of this law, after the issuance of the sentence, and before sending it to the court, whenever the plaintiff declares his final consent to the prosecutor in forgivable crimes, the prosecutor will revoke the sentence if there is a case in the prosecutor's office. In this case, the endowment order is issued by the investigator. It is necessary to mention that according to Article 282 of the mentioned law, after sending the case to the court, the prosecutor cannot deviate from the principle of the accusation or its evidence and return or amend the indictment accordingly. In this case, he can only announce to the court the new reasons for or against the accused that are discovered or committed (Amini, 2014: 155).

In unforgivable crimes such as political crimes, whenever the plaintiff declares his final consent, the prosecutor can, if the conditions for issuing a restraining order are met, can deviate from the indictment and suspend the prosecution, and if as a result of the plaintiff's consent the type of punishment is changed. The prosecutor slowly deviates from the previous indictment and, accordingly, issues a new indictment (Amini, 2014: 155).

\section{Mediation Regulations on Criminal Affairs approved in 2015}

Mediation regulations are another important law that points to the important role of the Samans, and in this regulation, the declaration of crime through the Samans has been considered as an important goal, which is also true for political crimes. Today, mediation is increasing in various ways at the national and global levels, and this has been made possible through legislative and judicial measures, as well as through executive and even through the Samans; Fortunately, in Iranian law, after the enactment of the Code of Criminal Procedure in 1392, this important issue 
has become clearer and more feasible. In Iranian criminal law, as well as international law, mediation is a method by which the parties to a dispute, with the help of a third party, such as the Samans, seek to reach a common agreement; therefore, criminal mediation seeks to realize the famous theory of restorative justice and is considered as an important feature of this theory. The purpose of the mediation law is to prevent the density of criminal cases and to prevent criminals from being punished. This is important in Article 82 of the Code of Criminal Procedure of 1392, which has been considered and legislated by the legislature. Therefore, the conditions in the Code of Criminal Procedure of 1392 regarding the implementation of legalized mediation, including the penalties of the sixth, seventh and eighth degree, which can be suspended, are included. At the request of the accused and with the consent of the victim or the private plaintiff, he shall obtain the appropriate security, and on the other hand, during the two-month period for the accused, forgiveness or compensation is provided for the education. On the other hand, a third party, such as the Dispute Resolution Council or other institutions, agrees to
800

make the disputes between the accused and the victim or the plaintiff a compromise in order to avoid going to court and lengthy proceedings. It should be noted that according to the note of Article 82 of the Code of Criminal Procedure of 1392, the investigator can request the suspension of prosecution or referral to mediation from the prosecutor; It is necessary to mention that in order to better implement mediation in criminal matters, the regulation of mediation in criminal matters approved in 2016 has also been approved.

Article 82 of the Criminal Procedure Code of 1392 states that: "In the sixth to eighth degree criminal offenses that can be suspended, the judicial authority may, at the request of the accused and with the consent of the victim or private plaintiff, and by obtaining appropriate security, a term exceeding It shall not take more than two months for the accused to apply for a pardon or compensation for a crime. The judicial authority may also refer the matter to the Dispute Resolution Council or to a person or institution for mediation with the consent of the parties. The mediation period will not exceed 3 months. The deadlines mentioned in this 
article can be extended only once if necessary. If the plaintiff forgives and the matter is forgivable, the prosecution will be terminated. In other cases, if the plaintiff forgives or his damages are compensated or an agreement is reached on the payment, the defendant has no history of effective criminal conviction, after obtaining the defendant's consent, the prosecutor may suspend his prosecution for six months to two years. In this case, the prosecutor obliges the accused to comply with some of the provisions of this article, in compliance with the notes of Article 81 (this law, as the case may be. Also, in case of nonfulfillment of the agreed obligations by the accused without a valid excuse, at the request of the plaintiff or the private plaintiff, the suspension of the prosecution will be canceled and the prosecution will continue." However, it should be noted that the mediation process and conditions mentioned in Articles 81 and 82 of the Criminal Procedure Code adopted in 1392 must be based on the Mediation Regulations in Criminal Matters adopted in 2016; Because according to paragraph "c" of Article "1" of the said regulation: "Mediation process, a set of measures during which with the mediation management and with the presence of the victim and the accused and if necessary other persons effective in obtaining compromise from For example, family members, friends or colleagues, as well as members of the local community, relevant official, public or nongovernmental organizations, discuss and exchange views to resolve criminal disputes with each other, and if an agreement is reached, the minutes will be prepared. And it will be sent to the relevant judicial authority." (Habibi, 2007: 5).

\section{Law of the Dispute Resolution Council approved in 2015}

The Law on Dispute Resolution Council adopted in 2015 does not allocate a title as a non-governmental organization, but it can be stated that the duties and goals of the Dispute Resolution Councils can be stated as the same duties and goals of nongovernmental organizations that have the duty to resolve disputes. Political crimes have no role in the scope of the Dispute Resolution Council's duties, and therefore there is no mention of political crimes in this law.

The first experience of participatory justice officially dates back 
to 1312 . This year, our country witnessed the first example of a participatory justice system, which entered the country's legal system in accordance with the single article of the law on judicial and administrative affairs in Lorestan and the relevant regulations. According to a plan submitted to the National Assembly by the then government, the government was given the necessary legal rules (except for real estate registration and official documents) in order to organize the judicial and administrative affairs of the Lorestan region, be arranged and implemented in the form of regulations. The law provided for a three-member tribunal to try and resolve disputes between people, one of whom was a member of a local tribunal. The law gave the court the power to deal with criminal cases from a misdemeanor point of view and, if necessary, to use methods of settling hostility through compromise. The validity of this regulation was three years from the date of approval (Abbasi, 2003: 282). After the failure of the initial experience in the idea of formal participatory justice in the form of the above-mentioned laws and regulations, the next move of the legislature before the revolution was to pass a law entitled
"Law on the Judicial Affairs of Tribes and Towns". The law, which was drafted in the form of a single article, stipulates that in places where tribes and nomads are disarmed and settled, the Ministry of Justice has three-member committees (two) to deal with and resolve disputes with each other or those who disagree with them. To form an experienced judge and one person to select local people) and to resolve the relevant lawsuits according to the principles and laws through alderman methods and to correct the disputes (Abbasi, 2003: 284). Among the numerous cases that are brought to justice in different parts of our country every day, some are related to small and insignificant lawsuits that do not have a special legal complexity and it is not difficult to distinguish between them. Therefore, in 2000, in Article 189 of the Third Economic, Social and Cultural Development Plan of the Islamic Republic of Iran, the legislature established Dispute Resolution Councils with the aim of achieving a culture of peace and reconciliation and thus reducing referrals to the judiciary. Disputes arose for civil society. The Law on Dispute Resolution Councils, passed in 2015, states in Article 1: "In order to resolve disputes and bring peace and 
reconciliation

between

non-

governmental natural and legal persons, the Dispute Resolution Councils, abbreviated as 'councils', are under the supervision of the judiciary. And shall be formed in accordance with the conditions stipulated in this law. It seems that the legislature has assumed that decisions can be made in matters of lesser importance by using individuals who have the authority to make decisions about matters or to be considered trustees. (Taleghan Ghaffari, 2016: 1).

\section{Crime Prevention Law approved in} 2015

One of the basics of Saman can be considered as crime prevention (such as political crimes), which can be considered as the basis of the law on crime prevention approved in 2009 and 2015 . $^{6}$ On the other hand, the Law on Crime Prevention, passed in 1394, and in

\footnotetext{
${ }^{6}$ Article 6 of the Law on Crime Prevention adopted in 2009: "The duties of the Provincial Council for Crime Prevention are as follows:

1) Implementing the decisions and policies of the Supreme Council for Crime Prevention at the provincial level.

2) Development of provincial crime prevention programs.

3) Reviewing the approval and evaluation of provincial and city plans and programs for prevention and providing the necessary facilities and bases for its implementation.

4) Planning to share the views and opinions of citizens and residents of neighborhoods in the preparation and preparation of prevention programs.
}

the third paragraph of its fifth article, refers to the participatory criminal policy, which is stated in this article as follows: The judiciary is formed:

1) Preventing the implementation of the notification of the council.

2) Carrying out research and studies required for the pathology of the causes of crime and ways to prevent it through research institutions in the three forces and academic research centers and, if necessary, conducting the mentioned research independently and preparing and publishing periodic and annual statistical reports.

3) Identify ways to attract public participation and support nongovernmental organizations and nongovernmental organizations in crime prevention within the framework of the rules and regulations of the council.

5) Employing and attracting the participation of nongovernmental and public institutions in the implementation of prevention plans and programs. 6) Submitting regular and periodic reports on the implementation of provincial prevention plans and programs to the Crime Prevention Organization.

7) Guiding city councils to prevent crime and monitor their performance.

8) Predicting the budget and resources necessary for the implementation of provincial prevention plans and programs and announcing it to the Crime Prevention Organization. 
4) Receive statistics and information related to the duties of the council from the relevant agencies and institutions to analyze them and submit a report to the council.

5) Preparing and compiling a draft of the executive policies and national programs for crime prevention and obtaining reports and summarizing the results of the implementation of national plans and programs for submission to the council.

6) Performing secretarial affairs and other tasks assigned by the council.

In general, according to the Crime Prevention Law approved in 2015, Samans are the most important institutions that play a role in preventing crimes, such as political crimes, and all the programs in this field can be formed according to this issue.

\section{Executive Regulations on the}

Establishment and Activity of NonGovernmental Organizations approved in 2005

One of the most important laws that has established the foundations of non-governmental organizations is the executive regulations for the establishment and operation of nongovernmental organizations approved in
2005. According to Article 3 of the regulation, "the subject of the organization's activities includes one of the scientific, cultural, social, sports, artistic, philanthropic, charitable, humanitarian, women's affairs, socially disadvantaged, supportive, healthcare, rehabilitation, "It's the environment, the development, and so on, or a set of them. Therefore, it can be stated based on this article that the aim of the Samans is to investigate and support a certain group of society, especially in criminal proceedings, which is based on participatory criminal policy.

"Participatory criminal policy means the broad participation of civil society and the use of the power of the media, associations and citizens in response to the criminal phenomenon by involving the largest number of actors in criminal policy with all the cooperation that requires it." (Laserge, 2003: 239)

Involving people in criminal politics is beyond legitimate concern about its effectiveness, meaning that today prevention and security are issues that concern all members of society. Criminal policy seeks to open its doors to the public and seeks to get out of the ivory tower and bring justice to the people and to use local institutions and 
groups such as dispute resolution councils to settle disputes. Some see participatory criminal policy as an active method that aims to further educate responsibility and pave the way for local democracy to ensure greater security. Participatory criminal policy is completely in line with the goals of the judicial approach, because by assigning the investigation of some crimes to the people and local associations, the cases will be removed from the criminal process and will be investigated by those authorities, so as to prevent people from entering the process. Criminal and the judiciary, or if they enter, will prevent the criminal proceedings from continuing. Therefore, the use of informal participatory methods that are shared with different methods in managing the criminal phenomenon and responding to it is considered as a kind of judgment (Amini, 2014: 44-43).

\section{THE REALM OF POLITICS IN SAMANS}

The realm of politics in NGOs can be studied from two perspectives; one is that the most important feature of the Samans is that they are non-political, and the other is that declaring a crime that the Samans can declare can be a political crime that can be studied in two categories, which are examined below.

The non-politics of the Samans

One of the characteristics of non-governmental organizations is its non-political nature. Note 3 of Article 1 of the By-Laws of Non-Governmental Organizations states: "Non-political objectives include activities that are not covered by Article 1 of the Law on Parties" Simply put, not having political goals can be equated with not being a political party. According to the article, the party and the political organization are organizations that are established by a group of individuals based on a specific political policy and with goals and programs about the principles of governing the country and the political system and the legislative system; And according to Note 2 of Article 3 of the Executive Regulations of the Law on Parties, the ideology of the organization includes the same cases. Thus, the nonpolitical nature of Saman's goals means the absence of these characteristics, which can be assessed by examining the ideology, organizational structure, as well as the activities of the organization. The activities of a non-governmental organization also have non-political goals, the activities of which are based 
on having an organizational policy on the principles of governing the country in various fields, the constitution and other laws, powers and pillars of the political system are not mechanisms for delegating and exercising power and the like; They also focus on political developments, elections, and do not work to gain sovereignty and political power. However, in addition to being non-profit, these organizations are also non-political. The entry of Samans into political work will not only divert them from the main goals of the organization, but will also introduce them as political parties. Being is that if they enter into political affairs, their occupations will be close to the functions of political parties (Ramezani Ghavamabadi, 2015: 544).

\section{ANNOUNCEMENT} POLITICAL CRIME BY THE SAMANS

One of the most important goals of the Samans is to prevent crime, protect the public interest and the right to declare a crime in the judiciary. Article 66 of the Code of Criminal Procedure, despite the change in its content and notes in recent years, shows the distance from monopolies and the relative acceptance of the presence of non-governmental
806 organizations in the criminal process (Eidani, 1397: 1). By recognizing the right to declare a crime, participation in all stages of the proceedings to provide evidence and objections to the rulings of the judiciary for the Samans was suddenly a fundamental change in their presence in the criminal process. With the introduction of the issue of the executive obstacles of the Code of Criminal Procedure, the implementation of the mentioned law was prevented and changes were made in it, and Article 66 was also subject to these changes. With the changes made in 2015, the right of protest of the Samans to the votes of the judicial authorities mentioned in Article 66 was eliminated and the hope created did not last long and turned into despair. Identifying the right to report a crime, participating in all stages of the trial to present evidence and protesting the rulings of the judiciary for the Samans is one of the missing links in our legal system in the criminal process. The core of the Samans' presence in this process was their right to reason and protest against the rulings of the judicial authorities. Therefore, it can be said that one of the crimes that the Samans can commit is a political crime.

\section{CONCLUSION}


The relationship of the Samans

with politics is a complex issue that the legislator in Article 66 of the Code of Criminal Procedure adopted in 1392, unlike other existing laws and regulations mentioned in this article, has delineated and carefully examined; Despite the fact that the Samans cannot be political and political affairs such as elections and other political issues can be involved, they can be recognized as declaring a political crime, and this is what is mentioned in the 1392 Criminal Procedure Code. Unfortunately, the existing laws and regulations on the subject of research mentioned in various parts of the article did not mention any definition of political crime until before the nineties, and the examples of political crime were hidden from the legislature and jurists. In some ways, the policy governing the Samans is unclear, and there is no clear demarcation in this regard. The legislature in 1392 has studied the subject of the Samans as much as possible and their intervention in political crimes and their existence.

\section{REFERENCES}

\section{Books}

1. Ashoori, Mohammad (2012). Criminal Procedure, Ch 16, Vol. 1, Tehran: Samat.

2. Ashoori, Muhammad (1997). The Harmful Role of Crime and Its Transformation in Criminal Lawsuits, in Criminal Justice Collection, Ch 1, Tehran: Ganj-e-Danesh.

3. Amini, Mohammad (2014). Dejudiciary and its place in the Iranian criminal system, Ch. 1, Tehran: Majd.

4. Rahgosha, Amir Hossein (2004). A Look at Dispute Resolution Councils, $\mathrm{Ch}$ 2, Tehran: Daneshvar Publications.

5. Abbasi, Mostafa (2003). New Horizons of Restorative Justice in Criminal Mediation, Ch. 1, Tehran: Daneshvar Publications.

6. Faramarz Gharamlaki, Ahad (2009). Ethics in Non-Governmental Organizations, Ch 1, Tehran: President. 7. Faramarz Gharamlaki, Ahad (2006). Principles and techniques of research in the field of religious studies, $\mathrm{Ch}$ 2, Qom: Seminary Management.

8. Goldost Joybari, Rajab (2014). Criminal Procedure Code, Ch. 1, Tehran: Jangal.

9. Giddens, Anthony (1383). Sociology, Ch 13, Tehran: Ney.

10. Lazerge, Christine (2003). An Introduction to Criminal Policy, 
translated by Dr. Ali Hossein Najafi Abrandabadi, Ch 1, Tehran: Mizan.

11. Niebur Reinhold (1932) Moral Man and Immoral Socity, New York: Oxford University.

12. Scott, John \& Marshal (2005) Gordon Oxford Dictionary of Sociology, New York: Oxford University Press.

\section{Journal}

1. Hosseini, Seyed Mohammad (1999). "The role of mediation in litigation and responding to violations of norms", Journal of the Faculty of Law and Political Science, pp. 45, 41-5.

2. Ramezani Ghavamabadi, Mohammad Hossein (2015). "Comparative study of the legal status of non-governmental organizations in Iran and France; from establishment to activity", Comparative Law Studies, Vol. 2: 567-541.

\section{Thesis}

3. Taleghan Ghaffari, Mehdi (2016). "Competence of the Dispute Resolution Council in handling legal cases", M.Sc. Thesis, Islamic Azad University, Tehran Branch.

4. Eidani, Fatemeh (1397). "The Role of Non-Governmental Organizations in Crime Prevention and Repetition", Master's Thesis, Islamic Azad University, Safa Dasht Branch.

\section{Handbook}

1. Habibi, Rahman (1386). "Criminal Mediation Booklet, A Way to Punishment", Mahallat Prison Administration 